\title{
BIOARCHEOLOGICKÉ PRŮZKUMY OSTATKŮ SVATÝCH Z KATAKOMB A JEJICH TRANSLACE V OBDOBÍ BAROKA DO VÝZNAMNÝCH MÍST V JIŽNÍCH ČECHÁCH
}

\author{
ZUZANA THOMOVÁ - TEREZA ŠÁLKOVÁ - ERIKA PRŮCHOVÁ - JAN JOHN - \\ ALEXANDER CHERKINSKY
}

\begin{abstract}
Abstrakt: Předmětem a cilem této studie je vyhodnoceni bioarcheologických průzkumů ostatkůz relikviárüu, ve kterých by podle pisemných pramenů měly být uloženy ostatky svatých původem z řimských katakomb, a jejich translace $v$ obdobi baroka do významných mist v jižních Čechách. Jedná se o značně nestandardní památky, jejichž výzkum a interpretace je sama o sobě netypická - zpưsobem uložení, př́stupem $k$ tomuto tématu ze strany církve i prostředím, ze kterého byly ziskané. Na přikladu dvou svatých z katakomb, tzv. martyrů, sv. Auraciána z kostela sv. Mikuláše v Českých Budějovicích a sv. Felixe z kostela Nejsvětějši Trojice u Nové Bystřice, lze popsat celý proces preneseni ostatkủ z řmských katakomb do Čech, a to za pomoci bioarcheologických metod, které archeologie využivá k rekonstrukci minulých populací. Radiokarbonové datováni prokazuje, že ostatky jsou skutečně z doby ř́mské, a jejich přenesení do prostoru středni Evropy $v$ raném novověku je tak reálným obrazem barokni zbožnosti.
\end{abstract}

Klićová slova: bioarcheologie - ostatky - relikviáře - katakomby - archeologie individuality.

Bioarchaeological research into the relics of saints from catacombs and their translocation to major sites in South Bohemia in the baroque period

Abstract: The subject and the objective of this study is the assessment of bioarchaeological research into relics from reliquaries which, according to written sources, held the relics of saints from Roman catacombs, as well as their translocation to important sites in South Bohemia in the baroque period. Relics are rather unusual historical phenomena the very research and interpretation of which are unconventional, based on the manner of depositing, approach to the subject on the part of the church and the environment from which they originate. An example of the relics of two saints from catacombs, the martyrs St. Auratian from the Church of St. Nicholas in České Budějovice and St. Felix from the Church of the Holiest Trinity near Nová Bystrice, serves to describe the process of the transfer of relics from Roman catacombs to Bohemia, with the help of bioarchaeological methods employed in archaeology in order to reconstruct past populations. Radiocarbon dating showed that the relics were indeed from the Roman period, and their transfer to central Europe in the early modern age thus aptly illustrates baroque religiousness.

Key words: bioarchaeology - relics - reliquaries - catacombs - archaeology of individuality.

\section{Kult světců z katakomb}

Termínem „svatí z katakomb“ jsou označovány ostatky domnělých raně křest’anských mučedníků, jejichž kostry nebo části těl byly, počínaje raným novověkem, po tisících vyjímány z římských katakomb a rozváženy po celé katolické Evropě. Tyto ostatky se těšily velké úctě věŕících. Počátky barokního kultu katakombálních mučedníků sahají do roku 1578, kdy byl díky náhodnému propadu půdy na Via Salaria v Ř́mě objeven vstup do dávno zapomenutých raně křest’anských podzemních pohřebišt'. Nález podnítil zájem o římské katakomby, které začaly být postupně prozkoumávány (Prokopová 2010, 530-531; Ryneš 1948, 8-9; Kadlec 1991, 111; Bažantová 1992, 3).

Velký zájem o těla vyzvedávaná z římských katakomb úzce souvisel se závěry tridentského koncilu, který na svém 25 . zasedání konaném v roce 1563 vydal 4. prosince dekret De invocatione, veneratione et reliquiis sanctorum, et sacris imaginibus, v němž je vyslovena podpora uctívání světců a jejich ostatků. Tím byl podnícen nejen rozvoj světecké úcty, ale rovněž i kultu ostatků. Svatí z katakomb přitom sehráli v tomto vzedmutí nového zájmu o relikvie významnou roli, nebot' díky znovuobjevení podzemních pohřebišt' byly náhle k dispozici desetitisíce těl domnělých raně křest’anských mučedníků. Bez přísunu takovéhoto obrovského množství nových relikvií by široký rozmach barokního kultu ostatků nebyl prakticky myslitelný (Prokopová 2010, 
$528,530,535)$. Pohřby z katakomb byly obecně pokládány za ostatky martyrů z počátečního údobí křest’anské církve, a to přesto, že již nebylo možné zjistit jejich jméno ani způsob úmrtí.

Za spolehlivou indicii dokládající mučednictví byl v raném novověku pokládán výskyt křest’anských symbolů na kamenné desce kryjící hrob nebo některé předměty nalezené v hrobě (tzv. lahvičky či ampule s krví mučedníka - ampullae sanguinis - blíže Borový 1869; Prokopová 2010, 532-533; Ryneš 1948, 9). Jestliže nebyla dochována epigrafická památka či jiný zdroj poskytující informaci o jménu pohřbené osoby, byla těmto anonymním světcům jména přidělována, v latině a italštině se pro tento proces pojmenování užívá výrazu „křtít“.

Všechny oficiálně uctívané ostatky musely být v raném novověku opatřeny autentikou, písemným certifikátem ověřujícím původ a pravost svatých ostatků, který mohl vydat jen $\mathrm{k}$ tomu kompetentní církevní hodnostář. Řada ostatků byla po převozu na nové, geograficky vzdálené místo spjata s různými legendickými příběhy a duchovními tradicemi vážícími se k těmto mučedníkům (Prokopová 2010, 533-534; Bažantová 1992, 3). Praxe přidělování umělých jmen podle speciálních seznamů měla za následek vysoký výskyt svatých ostatků shodného jména. Nezřídka byli proto tito mučedníci z katakomb zaměňováni a ztotožňováni s tradičními světci téhož jména. K těmto záměnám docházelo již v době baroka ze strany věŕících (např. Prokopová 2010, 563) i v průběhu 19.-21. století.

\section{Průběh průzkumu ostatků svatých}

Průzkum ostatků sv. Auraciána proběhl v roce 2014, kdy se Děkanství u sv. Mikuláše v Českých Budějovicích obrátilo prostřednictvím ThDr. Zdeňka Mareše na archeologické oddělení Jihočeského muzea v Českých Budějovicích se žádostí o antropologický průzkum a zjištění stáří ostatků. Samotný průzkum proběhl za značně ztížených podmínek 18. listopadu 2014 pří-

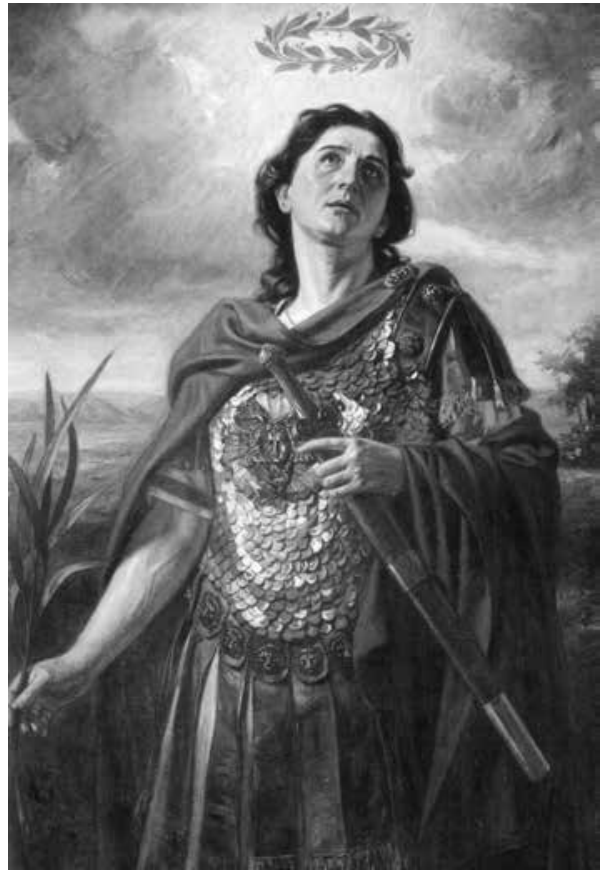

Obr. 1. Obraz sv. Auraciána od Františka Bohumila Doubka z roku 1912, kostel sv. Mikuláše, České Budějovice.

Abb. 1. Bild des Hl. Auratianus von František Bohumil Doubek aus dem Jahr 1912, St. Nikolauskirche, České Budějovice. mo na místě v sakristii kostela sv. Mikuláše. Tento požadavek průzkumu na místě vzešel ze strany církve a s ostatky bylo možné nakládat pouze $\mathrm{v}$ prostoru sakristie, vzhledem $\mathrm{k}$ tomu, že se jedná o církví oficiálně uznaného světce a patrona města Českých Budějovic, který byl slavnostně uložen do kostela 4. srpna 1670. Z tohoto důvodu byla situace $\mathrm{v}$ relikviáři pouze fotograficky dokumentována, antropologický posudek byl vypracován na místě a $\mathrm{k}$ dispozici na odběr vzorků bylo pouze nepatrné množství osteologického materiálu - jeden drobný zlomek dlouhé kosti. Kvůli velikosti vzorku musel být tento upraven a jako datovací materiál byl získán bioapatit (více zpráva Cherkinsky-Šálková 2014). Tento vzorek postačil pouze na radiokarbonové datování.

Obdobný postup byl uplatněn i při průzkumu ostatků sv. Felixe v kostele Nejsvětejší Trojice v Klášteře u Nové Bystřice. Tento průzkum proběhl v roce 2018 a jeho iniciátorem bylo město Nová Bystřice ve spolupráci s farností Nová Bystřice a ThDr. Františkem Holečkem. I v tomto případě proběhlo antropologické posouzení přímo na místě v kostele, některé součásti relikviáře byly $\mathrm{k}$ dispozici pouze vizuálně. Vzhledem $\mathrm{k}$ většímu množství 


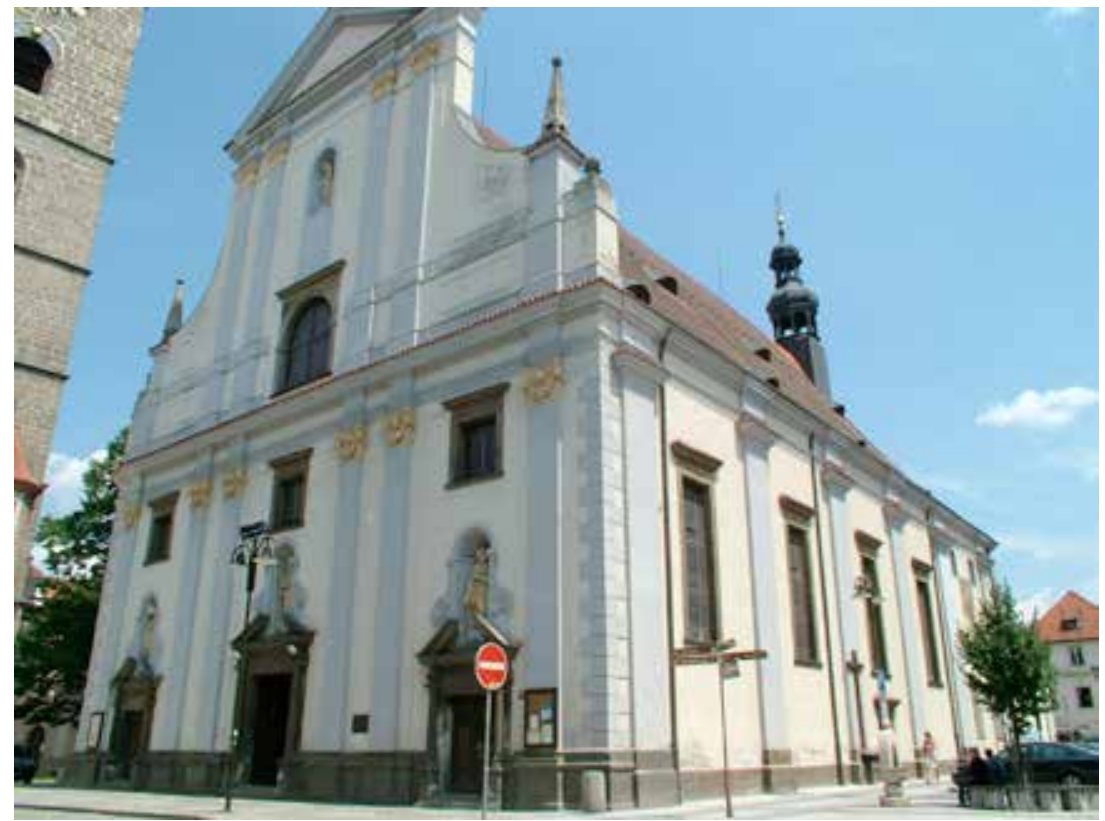

Obr. 2. Katedrální kostel sv. Mikuláše v Českých Budějovicích. Abb. 2. Kathedrale St. Nikolaus in České Budějovice.

dochovaného osteologického materiálu byl k dispozici i větší vzorek kosti na radiokarbonové datování (více zpráva Cherkinsky-Š́lková 2018).

\section{Sv. Auracián, kostel sv. Mikuláše, České Budějovice}

Ostatky přisuzované sv. Auraciánovi, patronovi Českých Budějovic (obr. 1), byly uložené ve výklenku v severním zdivu jižní chórové kaple kostela sv. Mikuláše v Českých Budějovicích (obr. 2) ve zdobeném barokním relikviáři, který nechal zhotovit děkan P. Tomáš Josef Cuculus (1651-1665). Tento nový světec byl do Českých Budějovic přenesen po velkém požáru v roce 1641 a do kostela slavnostně uložen až v roce 1670 (Kovář-Thomová 2017, 632-633). Ověřovací listina $\mathrm{s}$ apoštolským listem, ve které papež zakazoval rozdělení relikvie, pochází z roku 1643 (Reban 1918, 427-428). Podle legendy se jednalo o mladého římského vojáka, který žil ve 2.-3. století a který byl umučen v době pronásledování křest’anů (více Svatý Auracián v českobudějovické katedrále 2015, 17).

Výzkum ostatků probíhal v souvislosti s restaurováním relikviáře majitelem - v tomto případě Děkanstvím u sv. Mikuláše v Českých Budějovicích. Všechny zkoumané relikvie byly zdokumentované, antropologický materiál byl analyzován na místě a po základním konzervátorském ošetření vrácen do relikviáře. Vyjmut byl pouze drobný zlomek dlouhé kosti, který posloužil AMS radiokarbonovému datování.

\subsection{Antropologie}

Ve schránce se vedle lebky nacházelo i několik zlomků kostí postkraniálního skeletu. Zatímco fragmenty kostí byly v relikviáři uloženy volně, lebka byla na temeni dekorována mohutnou ozdobou tvořenou drátěnou konstrukcí s korálky a vavřínovými listy a skrz tuto ozdobu 


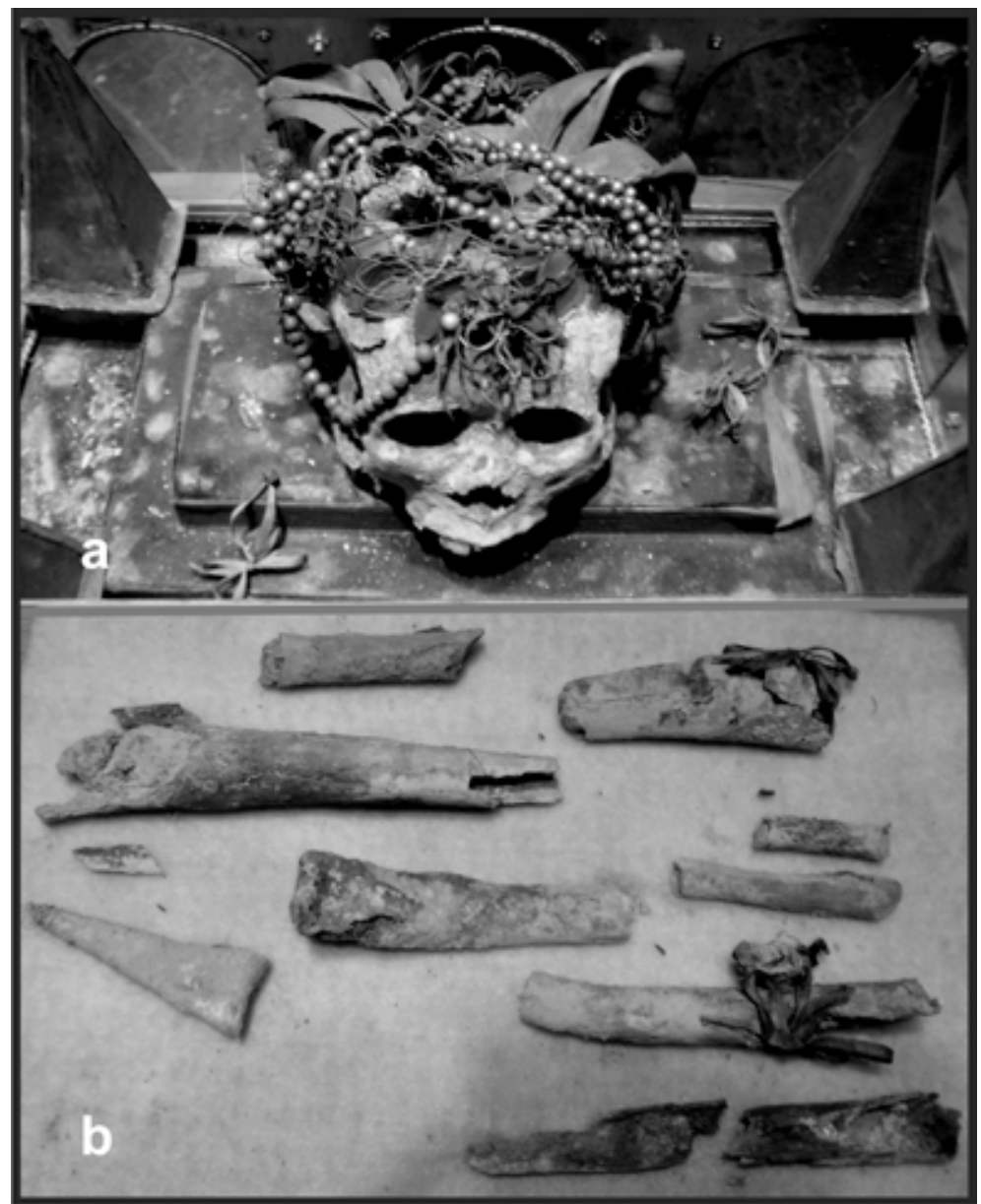

Obr. 3. Kosterní pozůstatky sv. Auraciána. a - lebka připevněná k podložce; b - několik větších zlomků kostí postkraniálu, na některých je patrné zdobení. Foto E. Průchová.

Abb. 3. Knochenüberreste des HI. Auratianus. a - an der Unterlage befestigter Schädel; b - mehrere größere Knochenfragmente des Postkranialskeletts, an einigen ist die Verzierung zu sehen. Foto E. Průchová.

připevněna $\mathrm{k}$ podložce (obr. 3a). Kvůli těmto dvěma okolnostem bylo do jisté míry omezeno následné hodnocení. Některé z kostí na sobě měly zbytky pozlacení a ovázání (obr. 3b). V rozích relikviáře se nacházely čtyři nízké obaly ve tvaru pyramidy naplněné neznámým materiálem, nejspíše drobnými rozpadlými kůstkami a jejich částmi.

Na základě makroskopického pozorování kompaktní a spongyozní kostní tkáně a morfologie kostí a jejich zlomků (Dobisíková-Eliášová 2012, 221-222; France 2009) byly kosti přiřazeny člověku. S ohledem na absenci opakujících se kostí či charakteristických znaků na zkoumaných ostatcích (Buikstra-Ubelaker, edd., 1994, 9) lze předpokládat, že zde byl pochován minimálně jeden jedinec.

\section{Metody}

Pro vyjádření kvantitativní míry zachovalosti jsme použili upravenou metodu Stojanowski-Seidemann-Doran (2002), která zhodnocuje stupeň zachovalosti na základě kosterních 
a zubních znaků. Byly vybrány takové znaky, které mají význam při demografických odhadech kostry. Stojanowski-Seidemann-Doran (2002) sestavili seznam 35 párových a 10 nepárových znaků, což je celkem 80 možných pozorování pro jednoho jedince. Každému znaku byla přiřazena bud' hodnota „skórovatelný/přítomný“, když byl znak dochován, a to i v př́ípadě patologických nebo kulturních modifikací znaku, nebo „neskórovatelný/poškozený“, když byla morfologie poškozena postdepozičními procesy, a tím redukována použitelnost pro odhady. Po zhodnocení všech znaků se vypočítává IS (individuální skóre) jako součet všech přítomných znaků, skóre zubů dolní a horní čelisti a výsledné číslo se vydělí 80 , což je celkový počet pozorování (Stojanovski-Seideman-Doran 2002).

\section{Věk dožití}

Ostatky byly ve velmi špatném stavu a nebylo možné použít žádnou vhodnou metodu odhadu věku dožití. V zubním oblouku horní čelisti se dochovaly pouze tři zuby (pravý první a druhý řezák a mesiodens). Na základě nedotvořené incisní hrany prvního řezáku bychom mohli zvolit metodu založenou na mineralizaci zubů (Ubelaker 1989). Pro hodnocení podle míry opotřebení kousací plochy (Lovejoy 1985) je jeden zub nerelevantní.

U kostí postkraniálního skeletu jsme mohli sledovat pouze stav osifikace kostry, tedy uzavření růstových štěrbin (Ferembach-Schwidetzky-Stloukal 1980).

\section{Pohlavi}

Vzhledem ke stavu zachovalosti jsme použili metodu založenou na hodnocení znaků na lebce (kombinace metod Buikstra-Ubelaker 1994; Ferembach-Schwidetzky-Stloukal 1980). Jedincům mohou být přiřazeny tyto hodnoty: žena $(F)$, muž $(M)$, indiferentní jedinec (I - v př́ipadě, že nebylo možné rozhodnout, zda jsou znaky charakteristické spíše pro ženu, či pro muže), pohlaví neurčeno (týká se především jedinců se špatnou zachovalostí, kde absentují znaky potřebné pro odhad pohlaví).

\section{Výsledky}

Míra zachovalosti z kvantitativního hlediska byla velmi špatná, pouhých 15,6\%. V relikviáři byla $\mathrm{k}$ podstavci připevněna lebka se dvěma horními pravými řezáky druhé dentice a zbytky kostí postkraniálního skeletu se nacházely kolem něj. Identifikovat se podařilo zlomky těl pažních kostí, distální konec pravé vřetenní kosti, články prstů ruky, zlomky těl stehenních kostí a distální konec pravé holenní kosti. Rovněž kvalitativní zachovalost nebyla př́liš dobrá. Kosti byly křehké, křídovité, jejich povrch se drolil a místy byly pokryté jakýmsi sintrem. Kosti postkraniálního skeletu bychom přiřadili $\mathrm{k}$ jedinci juvenilnímu až dospělému, který byl starší patnácti let. Tento předpoklad je založen na kompletní osifikaci distálních konců vřetenní a holenní kosti. U lebky je odhad komplikovaný, pokud vůbec možný. Ačkoli byly přítomny oba horní pravé řezáky, podle jejichž stavu mineralizace a erupce bychom jedince odhadli na 8 let \pm 24 měsíců, tak nám tento odhad ztěžuje přítomnost nadpočetného zubu (mesiodens, viz níže).

Sledované pohlavní znaky na lebce vykazovaly spíše ženské hodnoty. S ohledem na neodhadnutý věk dožití podle zubů jedince berme tento odhad s rezervou. K plnému rozvoji pohlavních znaků dochází u jedince až s dosažením jeho dospělosti (Buikstra-Ubelaker, edd., 1994, 16; Dobisíková 1999, 168). Znak s nejvyšší váhou (3), kterým byla glabella, vykazoval hyperfemininí formu. Stejně tomu bylo u margo supraorbitalis, dále u znaku processus zygomaticus (váha 3), arcus superciliaris (váha 2) či sklonu čelní kosti (váha 1). Uvedené znaky vykazují co nejmenší míru překrývání, a tím vykazují míru spolehlivosti (Dobisíková 1999, 168).

Kosti postkraniálního skeletu, stejně jako lebka, byly gracilní, což by podporovalo domněnku, že se jedná o kosterní ostatky jednoho jedince a ženského pohlaví. Není to ovšem signifikantní odhad pohlaví. Vzhledem k absenci kompletní kosti dlouhého typu, kterou by bylo možné změřit, nebylo možné odhadovat výšku postavy.

V zubním oblouku horní čelisti jedince jsme identifikovali kořen vmezeřeného zubu (obr. 4). První pravý horní řezák byl posunut laterálně od středové linie. A ačkoli se pravděpodobně 


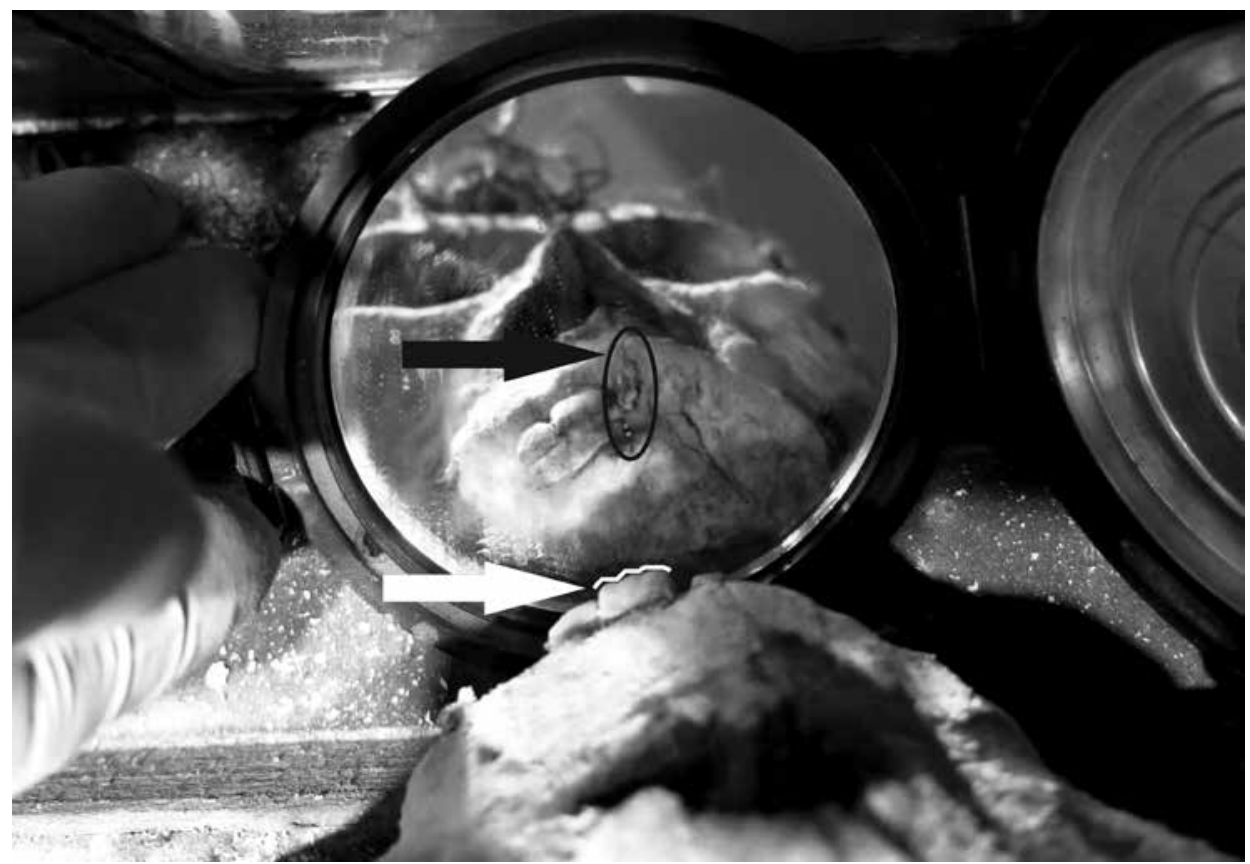

Obr. 4. Zubní anomálie sv. Auraciána: vmezeřený zub mezi horními centrálními řezáky (mesiodens v černém oválu); pouze částečně prořezaný horní první řezák, jehož reliéf incizní hrany je zvýrazněn bílou linií. Foto E. Průchová.

Abb. 4. Zahnanomalie des HI. Auratianus: überzähliger Zahn zwischen den oberen zentralen Schneidezähnen (Mesiodens im roten Oval); nur teilweise durchgesägter oberer erster Schneidezahn, dessen Relief des Inzisionsrandes durch eine weiße Linie hervorgehoben wird. Foto E. Průchová.

jednalo o dospělého jedince, zub vykazoval dosud známky vývoje. Jeho okluzní plocha byla ještě stále zvlněna a nebyla plně dotvořena. Zubní anomálii na základě fotografické dokumentace posoudil MUDr. M. Lívanec: „Horní první pravý řezák je skutečně posunut laterálně z důvodu přespočetného zubu. Tento kořen je nejspišse radix přespočetného zubu. Pokud je lokalizován mezi hornimi řezáky jako zde, nazývá se mesiodens. Řekl bych, že se jednalo o genetickou vadu nejen v přespočetném zubu, ale i dva zuby vedle jsou jen částečně prořezané, soudě podle reliéfu incizni hrany jedničky, která se na kousáni nejspíše vůbec nepodilela. Škoda, že se nedochoval i nějaký plně prořezaný zub na posouzeni." V případě nálezu kořene zubu ve středové linii horní čelisti se jedná o přespočetný zub, tzv. mesiodens. Jedná se o specifickou formu hyperdontie a její výskyt v populaci se odhaduje na $0,15-1,9 \%$ (Russell-Folwarczna 2003,362), respektive od 1 do $3 \%$ (Huber-Suri-Taneja 2008, 224; Henry-Post 1989, 59). Dále se uvádí, že třetina pacientů s mesiodens má další přespočetný zub (Russell-Folwarczna 2003, 362). Ve studiích o přespočetných zubech je rovněž zmiňována jejich souvislost s dalšími kraniofaciálními abnormalitami, jako je např́iklad rozštěp patra či rtu, kleidokraniální dysostóza (abnormality ve vývoji lebky a klíčních kostí) a Gardnerův syndrom (Russell-Folwarczna 2003, 362; Henry-Post 1989, 59). Etiologie mesiodens je nejasná, v úvahu se v současnosti berou tři teorie. Bez zajímavosti není ani fakt, že muži jsou touto zubní anomálií postiženi dvakrát častěji než ženy (RussellFolwarczna 2003, 362; Scheiner-Sampson 1997, 161; Henry-Post 1989, 59). Přítomnost nadpočetného zubu je nejčastější příčinou zpoždění, či dokonce absence prvních horních řezáků (Huber-Suri-Taneja 2008, 223; Russell-Folwarczna 2003, 362; Henry-Post 1989, 59). Četnost opožděného prořezání prvních horních řezáků druhé dentice se v různých studiích lišila a pohybovala se mezi 26-60\% (Huber-Suri-Taneja 2008, Tab. 4, 223). Př́tomnost vmezeřeného zubu 
(mesiodens) může ovlivnit nejen postup prořezávání druhých zubů, ale i jejich polohu či tvar (Russell-Folwarczna 2003, 362; Henry-Post 1989, 59) a vzorec prořezání může být asymetrický (Meighani-Pakdaman 2010, 44). Tento fakt v našem př́ípadě výrazně omezil odhad věku dožití.

Vedle této výrazné anomálie jsme identifikovali pravděpodobně zlomeninu pravé holenní kosti, která byla zhojená. Zda se jednalo skutečně o zlomeninu, by potvrdilo, respektive vyvrátilo rentgenové vyšetření.

\subsection{Radiokarbonové datování}

Pro radiokarbonové datování byl odebrán jeden drobný zlomek dlouhé kosti. Z kosti byly získány dva vzorky. Z prvního byl extrahován vosk, kterým byla kost napuštěna, a z druhého byl získán uhlík z bioapatitu (tj. minerální část kosti). Vzorek kosti byl př́liš malý, z bioapatitu bylo možné získat pouze 134 mikrogramů uhlíku. Datování bylo provedeno metodou AMS (Cherkinsky 2009). Měřen byl radioaktivní izotop 14C a stabilní izotop 13C (UGAMS 19564, tab. I). Kalibrace byla provedena pomocí programu OxCal (Bronk Ramsey 2013) za použití kalibrační křivky IntCal13 (Reimer et al. 2013, graf 1). Výsledky shrnuje tabulka 1.

Vosk byl datován do rozmezí mezi koncem 15. a polovinou 17. století (1497-1646 AD). Vzhledem k tomu, že k přenesení ostatků do Českých Budějovic došlo v roce 1644, nelze spolehlivě rozhodnout, zda k úpravě kostí došlo před, anebo po jejich přenesení. Nicméně úpravy na kostech rozhodně proběhly až po jejich vyjmutí z katakomb, dataci vosku do doby smrti zkoumané osoby lze vyloučit. Vzhledem k druhotné manipulaci a nakládání s kostmi (kontaminace z vosku) byly samotné kosti datovány pomocí AMS datace bioapatitu, nikoliv kolagenu, jak bývá obvyklejší. Přesnost datace byla vzhledem k malému množství materiálu nízká. Vzorek kosti byl datován (po kalibraci) do rozmezí let 200 BC-131 AD. Vzorek mohl být ovlivněný naprríklad místními geologickými poměry nebo stravou pocházející z moře. Nicméně kalibrované datum zasahuje do druhého století našeho letopočtu a lze konstatovat, že ostatky zkoumané osoby pocházejí skutečně z období přelomu letopočtů.

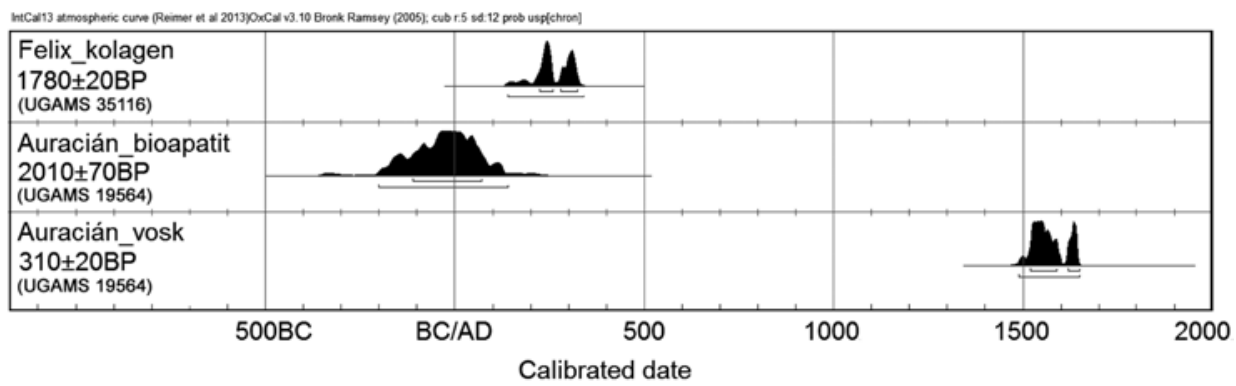

Tab. 1. Kalibrovaná radiokarbonová data (s přesností 2 sigma, tj. 95,4 \%) ze vzorků kostí z relikviářủ připisovaných sv. Auraciánovi a sv. Felixovi.

Tab. 1. Kalibrierte Radiokarbondaten (mit einer Genauigkeit von 2 Sigma, d.h. 95,4\%) von den Knochenproben aus den dem HI. Auriatianus und HI. Felix zugeschriebenen Reliquiaren.

\subsection{Dodatečné úpravy kostí}

Jak se ukázalo během radiokarbonového datování (viz výše), kosterní pozůstatky byly v novověku napuštěny včelím voskem. Došlo také k jejich pozlacení, jehož zbytky lze pozorovat na fragmentech postkraniálního skeletu (obr. 5), na lebce však nikoliv. Dle předběžného ohledání se zdá, že zlacením nebyl pokryt celý povrch kostí, ale kovová fólie tvořila nějaké ornamenty, snad spirálovité. Více by mohl prozradit další průzkum a konzervace ostatků. 
Za účelem posouzení složení zlaté fólie byl odebrán její malý vzorek o velikosti ca $1 \mathrm{~mm}^{2}$ a ten byl následně analyzován pomocí metody rentgenové fluorescence (RFA). Samotné měření probíhalo pomocí ručního spektrometru Niton XL2 GOLDD s velkoplošným Silikon Drift Detektorem (SDD) a nízkovýkonovou rentgenovou lampou $(45 \mathrm{kV} / 2 \mathrm{~W})$ se stř́brnou anodou. Výsledky měření jsou obsaženy $\mathrm{v}$ tabulce 2 . Na základě naměřených výsledků můžeme konstatovat, že fólie se skládá z poměrně čistého zlata - jeho ryzost je ca 23 karátů. Ve slitině byla zachycena př́měs stř́ibra (1,5\%), mědi $(1,2 \%)$ a zinku $(0,8 \%)$. Zachycené stopy železa jsou pravděpodobně stopou povrchového znečištění fólie.

Lebka sv. Auraciána je pevně spojena s relikviářem pomocí svislé kovové osy, v jejíž horní části je pohyblivý kroužek. Otvorem v týlní části lebky lze pozorovat textilní vycpávku uvnitř mozkovny. Na kalvě lebky je připevněn věnec vyrobený z kovových drátů, textilie, imitací perel a listů.

Rozměry listů jsou ca $21 \times 11 \mathrm{~mm}$. Může se jednat o napodobeninu vavř́nových listů (Laurus nobilis), které jsou ovšem zpravidla dvojnásobné velikosti, nebo o napodobeninu listů zimostrázu (Buxus sempervirens). V křest’anské symbolice se věnce z vavřínových listů užívá jako symbolu Kristova vítězství nad smrtí.

Při bližším pohledu na materiál listů je patrná jejich struktura, tvořená vzduchovými bublinkami (obr. 5). Materiál použitý pro výrobu listů nebyl dosud identifikován, podle měření RFA (tab. 3) můžeme pouze říci, že obsahuje značné množství vápníku a jeho zelené zbarvení je způsobeno mědí.

\begin{tabular}{|c|c|c|c|c|c|}
\hline RFA & Au & Ag & Cu & Zn & Fe \\
\hline Sv. Auracián - pozlacení & 95,08 & 1,47 & 1,17 & 0,78 & 1,16 \\
\hline
\end{tabular}

Tab. 2. Prvkové složení zlaté fólie podle RFA z výzdoby ostatků sv. Auraciána. V̌̌echny hodnoty jsou uvedeny v procentech. Tab. 2. Elementezusammensetzung der Goldfolie nach RFA von der Verzierung der Gebeine des HI. Auratianus. Alle Werte werden in Prozent angegeben.

\begin{tabular}{|c|c|c|c|c|c|c|c|c|c|}
\hline RFA & Cu & Ca & S & Al & Pb & K & P & Si & Cl \\
\hline Sv. Auracián - list & 36,12 & 28,65 & 10,17 & 13,94 & 3,64 & 1,61 & 0,86 & 1,70 & 1,49 \\
\hline
\end{tabular}

Tab. 3. Prvkové složení hmoty umělých listů z výzdoby ostatků sv. Auraciána (nejvíce zastoupené prvky). Všechny hodnoty jsou uvedeny $\mathrm{v}$ procentech.

Tab. 3. Elementezusammensetzung der Masse der künstlichen Blätter von der Verzierung der Gebeine des HI. Auratianus (am meisten vertretene Elemente). Alle Werte werden in Prozent angegeben.

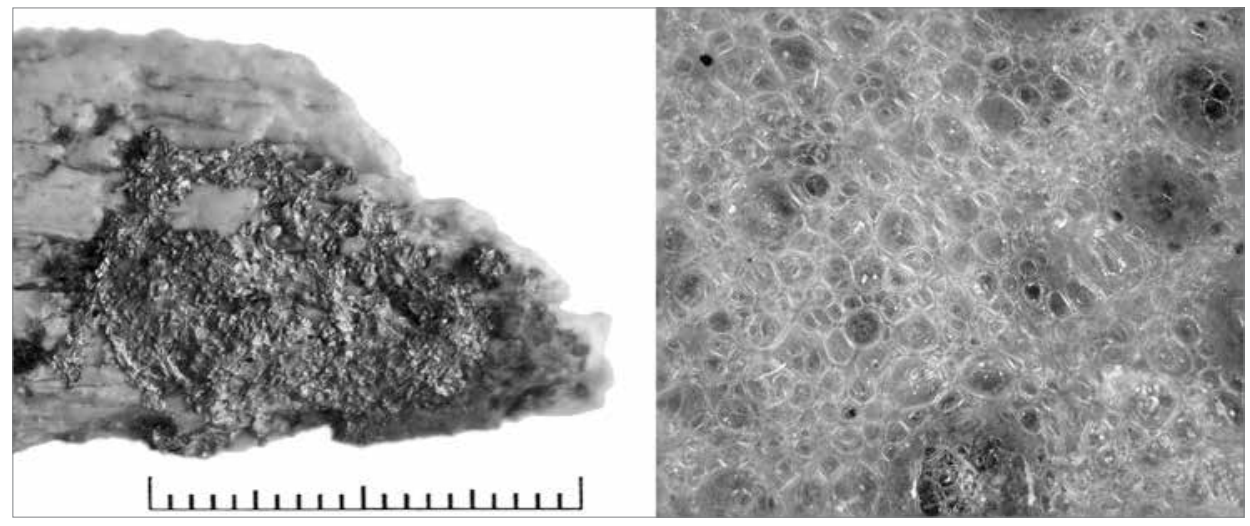

Obr. 5. Pozlacení kosterních pozůstatků sv. Auraciána; struktura umělých listů z věnce umístěného na hlavě. Foto J. John. Abb. 5. Vergoldung der Knochenüberreste des Hl. Auratianus; Struktur der künstlichen Blätter des auf dem Kopf befindlichen Kranzes. Foto J. John. 


\subsection{Závěr}

Bioarcheologický průzkum ostatků sv. Auraciána byl proveden před restaurováním relikviáŕe, který tyto ostatky obsahoval. Ostatky se dostaly do Českých Budějovic v polovině 17. století a dochovala se i jejich ověřovací listina z roku 1643, na základě které lze předpokládat, že lidské pozůstatky sledovaného jedince byly vyzvednuty z římských katakomb. Jejich míra zachovalosti byla velmi špatná, stejně jako kvalita kostí, které byly značně křídovité a křehké. K průzkumu ostatků byly použity - antropologie, radiokarbonové datování a podrobný rozbor výzdoby, kterou relikviár také obsahoval a která byla vytvořena nejspíše při přípravě slavnostní translace ostatků do kostela sv. Mikuláše, k níž došlo v roce 1670. Jedinec byl zařazen do kategorie dospělý, sledované znaky na lebce vykazovaly spíše ženské hodnoty, a tak byl jedinec odhadnut jako žena. Při průzkumu byl na lebce zjištěn vmezeřený zub, což byla deformace určená jako mesiodens. Vmezeřený zub byl lokalizován mezi horní řezáky. Jde o genetickou poruchu, která bývá doprovázena dalšími abnormalitami, jako je rozštěp patra nebo rtu, abnormalitami ve vývoji lebky nebo klíční kosti, Gardnerovým syndromem. Na pravé holenní kosti byla identifikována zhojená zlomenina. Malý vzorek kosti byl po kalibraci datován do období přelomu letopočtu, v horní hranici do 2. století. Před slavnostní translací došlo k úpravě kostí včelím voskem. Ostatky byly zlaceny spirálovitými ornamenty; zlatá fólie byla vyrobena z 23karátového zlata. Relikviář obsahoval i další výzdobu, na hlavě sledovaného jedince byl umístěn věnec z kovových drátků, textilie, perel a listů, jejichž materiál nebyl dosud identifikován.

\section{Sv. Felix, kostel Nejsvětější Trojice, Klášter u Nové Bystřice}

Tyto ostatky jsou připisovány Felixovi I., který byl papežem v době vlády císaře Aureliána. Jeho pontifkát je datován do rozmezí let 269-274. Zemřel 30. prosince a pohřben byl v Kalixtových katakombách v Římě. Do Čech se jeho ostatky dostaly díky řádu nejmenších bratř́i sv. Františka z Pauly v roce 1682. Translace ostatků měla širší dogmatický a eklesiologický význam. Pravost a neporušenost ostatků potvrdil 10. října 1682 pražský arcibiskup Jan Fridrich z Valdštejna, ale na rozdíl od autentiky náležející ke sv. Auraciánovi, tento dokument týkající se sv. Felixe je dnes nezvěstný. Ostatky daroval papež Inocenc XI. karmelitánskému generálovi Karlu Felixovi od sv. Terezie (Slavata z Chlumu a Košumberka) pro novobystřický kostel Nejsvětější Trojice, kde byly vystaveny ,úctě lidu“ na oltáŕi sv. Archanděla Michaela 28. října 1682 za prŕitomnosti celého slavatovského dvora (více Holeček 2017, 1-5). V současné době jsou ostatky uložené v několika dřevěných schránkách, relikviáŕích, na tomto oltáři v již zmiňovaném kostele Nejsvětější Trojice v Klášteře u Nové Bystřice (obr. 6).

\subsection{Antropologie}

Antropologickému zkoumání byly podrobeny lidské kosterní ostatky nacházející se ve velmi pietním uložení na oltáři ve schránkách. V centrální části se nacházela dvouetážová schránka. V horní části byla umístěna lebka, lopatky, obratle a zlomky pánevních kostí (obr. 7a). Ve spodní části se nacházely pažní, vřetenní, lýtkové a kyčelní kosti, dále žebra, křížová kost a některé kosti rukou a nohou (obr. 7b). Po stranách centrální schránky byly vztyčeny jehlancové schránky obsahující kosti dlouhého typu dolních končetin (stehenní a holenní kosti; obr. 8). Z pohledu člověka stojícího čelem ke schránkám se vlevo blíže k centrálnímu boxu nacházela levá holenní kost, která však směřovala proximálním koncem distálně. Od ní vlevo byla umístěna levá stehenní kost směřující k nám posteriorní plochou. Tato kost byla přibližně v polovině své délky zlomená. Vpravo od centrální schránky byla umístěna pravá holenní kost, opět otočená proximálním koncem distálně. Od ní vpravo byla umístěna pravá stehenní kost, která byla rovněž otočená posteriorní plochou k pozorovateli.

S výjimkou schránky s kompletní stehenní kostí a vrchní části centrální schránky s lebkou zůstaly ostatní schránky zavřené. Anatomické určení, věk dožití a pohlaví jsme tak odhadovali 


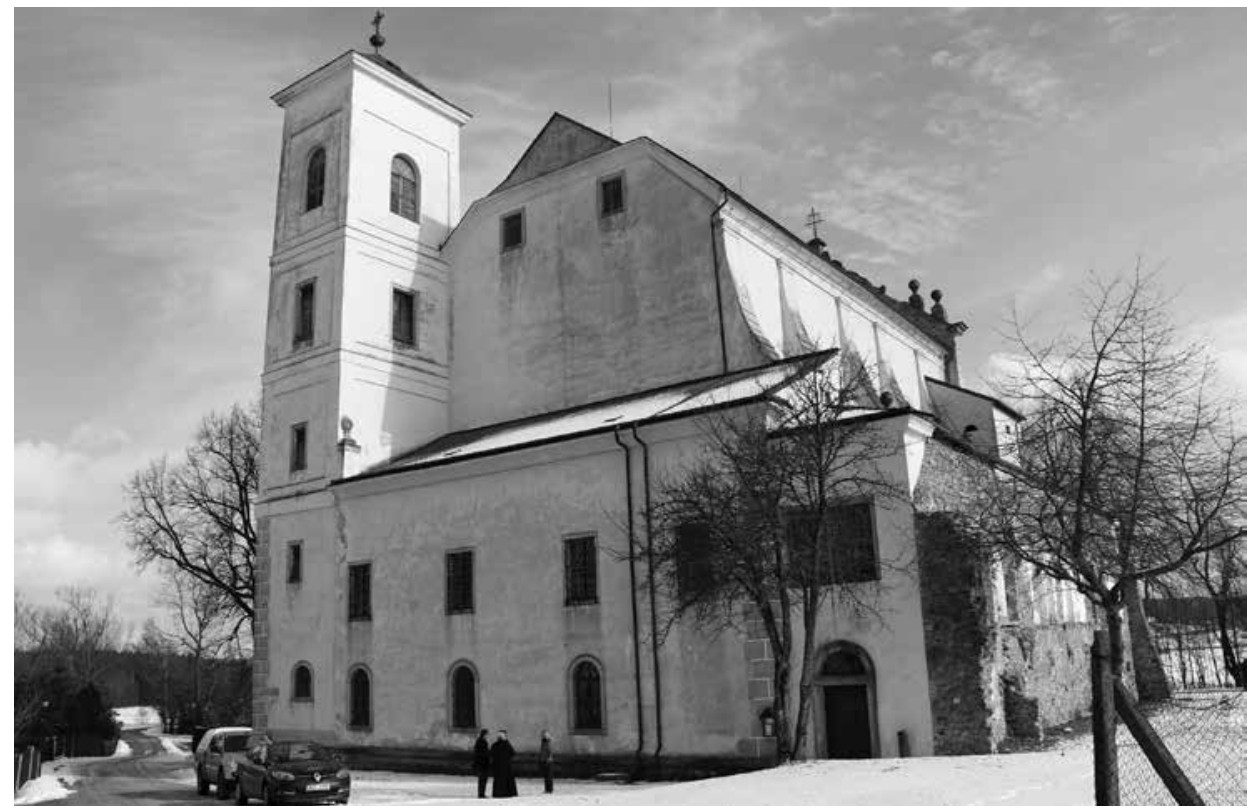

Obr. 6. Kostel Nejsvětější Trojice v Klášteře u Nové Bystřice. Foto L. Bílý. Abb. 6. Dreifaltigkeitskirche des Klosters bei Nová Bystřice. Foto L. Bílý.

pouze pohledem přes sklo. Vizuální hodnocení bylo v některých př́ípadech ztíženo zdobením kostí korálky, ozdobnými šňůrkami a umělými květinami. Jednalo se o sekundární uložení, ve kterém nebyl dodržen anatomický sled kostí. Anatomicky se podařilo určit téměř všechny kosti a jejich zlomky. Neopakovatelnost kosterních elementů, velikost a robusticita kostí nás vedla k závěru, že se jednalo o kosterní ostatky jednoho jedince.

\section{Metody a zachovalost}

Pro vyjádření kvantitativní míry zachovalosti jsme použili upravenou metodu Stojanowski-Seidemann-Doran (2002), která zhodnocuje stupeň zachovalosti na základě kosterních a zubních znaků, tedy byla použita shodná metoda jako v případě sv Auraciána. Byly vybrány takové znaky, které mají význam při demografických odhadech kostry. Stojanowski-Seidemann-Doran (2002) sestavili seznam 35 párových a 10 nepárových znaků, což je celkem 80 možných pozorování pro jednoho jedince. Každému znaku byla přiřazena bud' hodnota „skórovatelný/prrítomný“, když byl znak dochován, a to i v případě patologických nebo kulturních modifikací znaku, nebo „neskórovatelný/poškozený“, když byla morfologie poškozena postdepozičními procesy, a tím redukována použitelnost pro odhady. Po zhodnocení všech znaků se vypočítává IS (individuální skóre) jako součet všech přítomných znaků, skóre zubů dolní a horní čelisti a výsledné číslo se vydělí 80 , což je celkový počet pozorování.

Věk dožití

Pro odhad věku dožití kosterních ostatků jsme použili metodu založenou na stavu osifikace (Ferembach-Schwidetzky-Stloukal 1980). Metoda je založena na hodnocení stavu spojení růstových center jednotlivých kostí. Stav osifikace je rozdělen do tří kategorií: A - epifýza je zcela přirostlá k diafýze a rýha mezi nimi již není viditelná; $\mathrm{O}$ - spojení je ve stavu osifikace, což znamená, že centra nejsou oddělená, a pokud jsou již zcela přirostlá, tak je stále patrná rýha mezi nimi; N - epifýza s diafýzou jsou zcela oddělené. Věkové rozmezí konkrétního spojení se vyhodnocuje následovně: např́íklad rozmezí 15-20 let se stavem spojení A dává dílčí odhad $>15$, 

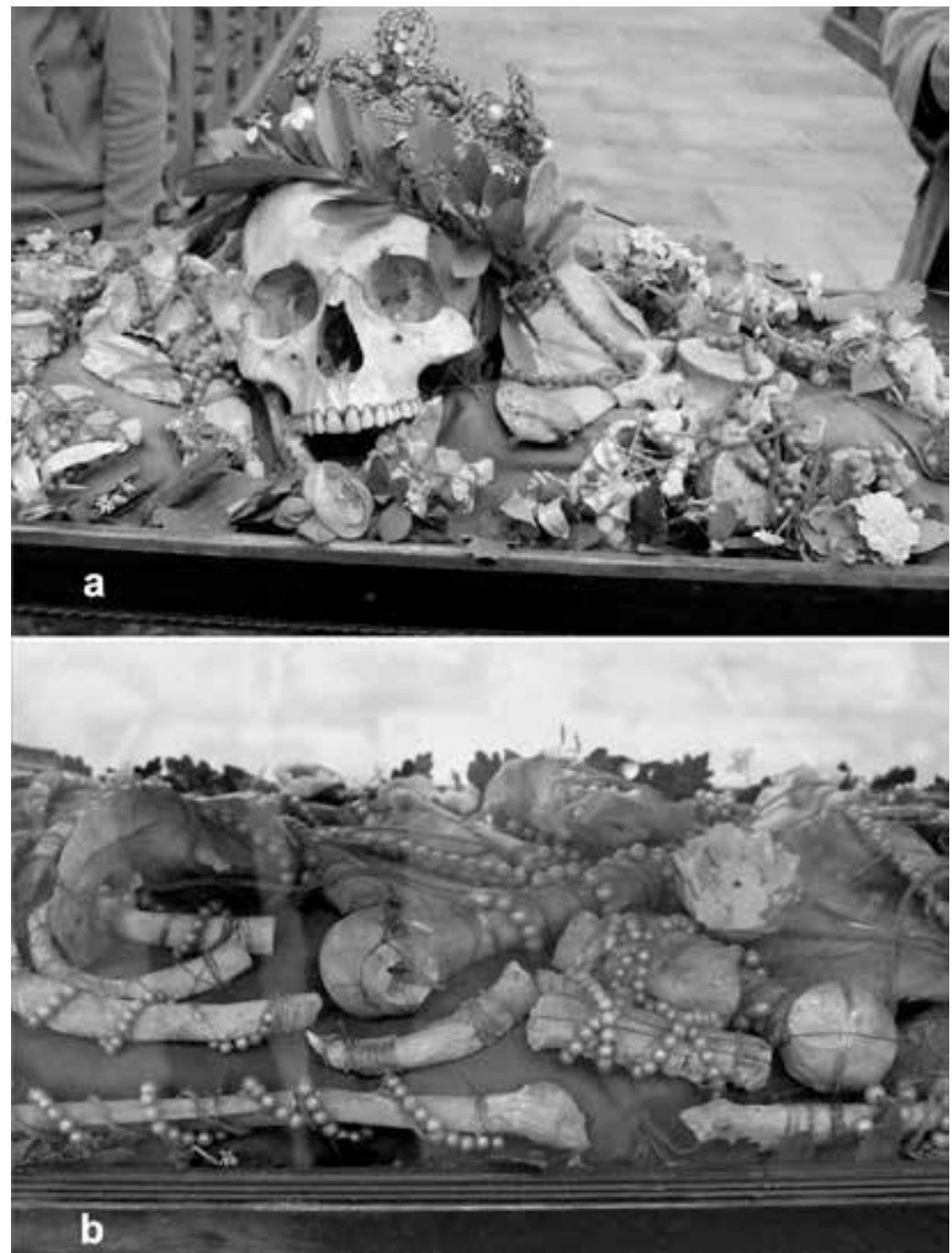

Obr. 7. Rozmístění a př́ístupnost kosterních ostatků sv. Felixe. a - vrchní část centrální schránky s lebkou, která byla otevřena; b - spodní část centrální schránky zůstala uzavřena a kosti byly hodnoceny pouze přes sklo. V obou případech vše ztěžovalo zdobení kostí korálky a květinami. Foto E. Průchová. Abb. 7. Verteilung und Zugänglichkeit der Knochenüberreste des HI. Felix. a - oberer Teil des zentralen Kastens mit Schädel, der offen war; $b$ - der untere Teil des zentralen Kastens blieb geschlossen und die Knochen wurden lediglich hinter Glas beurteilt. In beiden Fällen wurde alles durch die Verzierung der Knochen mit Perlenketten und Blumen erschwert. Foto E. Průchová.

se stavem spojení $\mathrm{N}$ je dílčí odhad $<20$, se stavem spojení O je dílčí odhad $15-20$. Odhad věku se zakládá na průniku dílčích odhadů, například $>18,15-20,<24$ dávají celkový odhad věku 18-20 let. Mezi ženami a muži je mírný rozdíl, kdy dochází k uzavírání epifyzárních štěrbin, což je v metodě zohledněno.

\section{Pohlaví}

Při zachování pánevních kostí preferujeme metodu založenou na zhodnocení jejich pohlavně specifických znaků podle metody Bruzek. Spolehlivost odhadu pohlaví podle znaků na 
pánevních kostech je dána tím, že se přizpůsobují reprodukčním a lokomočním tlakům. Tato metoda je spolehlivá v $95 \%$ př́ípadů s chybou u $2 \%$ a neschopností určit pohlaví u $3 \%$ (Bruzek 2002).

Spolehlivost metody je zachována i při hodnocení nekompletních kostí, kdy se posuzují jen některé oblasti (nejčastěji se jedná o tvar incisura ischiadica major a znak arc composé).

Výška postavy

Výpočet výšky postavy na základě měření délek kostí dlouhého typu (Sjøvold 1990) je prováděn pouze u kosterních ostatků dospělých jedinců. Metoda je založena na vztazích mezi kosterními elementy a výškou. Základem je naměření délky kosti dlouhého typu a jejím následným vložením do rovnice. Nevýhodou je různá proporce populací v prostoru a čase, kterou snižujeme užitím nejefektivnější kosti. Pro odhad výšky postavy jsme vybrali pravou stehenní kost. Schránka, která ji obsahovala, byla otevřena a kost vyjmuta. Její změření pomocí osteometrické desky zkomplikoval fakt, že byla připevněna k podložce, ze které nebylo možné ji sundat. Proto jsme přistoupili k naměření délky kosti za pomoci skládacího metru.

\section{Výsledky}

Míra zachovalosti kostry byla na základě upravené metody Stojanowski-SeidemannDoran (2002) odhadnuta na $81,5 \%$. Celkově jsou tedy kosterní ostatky velmi dobře dochovány a jsou téměř kompletní. V této souvislosti je proto zarážející absence obou loketních kostí. Absentují rovněž některé kosti rukou a nohou, pravá čéška a několik hrudních obratlů (Th 6-9 a Th 12).

Téměř všechny kosti jsou kompletní, nefragmentované, s kompaktním povrchem bez poškození například abrazí. Věk dožití jsme odhadovali podle stavu osifikace kosterních ostatků. Určující byly zejména čtyři znaky, a to kompletně přirostlá proximální epifýza pažní kosti, zcela nepřirostlý mediální konec klíční kosti a lem lopaty kyčelní kosti a ve stavu osifikace se nacházející sedací hrbol.

Podle stavu osifikace kostry jsme věk dožití jedince odhadli na 21-24 let. Na základě pohlavně specifických znaků na pánevních kostech jsme jedince odhadli jako muže.

Lebka měla jemnějš́ linie a některé znaky vykazovaly spíše ženskou formu. Týkalo se to především glabely a tvaru očnic. Pro odhad výšky postavy jsme použili naměřenou délku pravé stehenní kosti (44,4 cm). Na jejím základě jsme vypočetli výšku jedince na 161,7-170,7 cm.

V horní čelisti byla zhojená lůžka po pravé druhé a třetí stoličce a v dolní čelisti u pravé třetí stoličky. Zatímco s ohledem na odhadnutý věk jedince můžeme předpokládat, že k prořezání třetí stoličky nedošlo, ačkoli tento závěr nelze bez RTG snímkování potvrdit, u druhé stoličky se pravděpodobně jednalo o ztrátu vlivem úrazu či onemocnění. Na zubech se vyskytoval mírný zubní kámen. Jedná se o mineralizaci vrstev zubního plaku naléhajícího na zuby. Zdrojem minerálů jsou sliny. Mechanismus, který mineralizaci spouští, je nejasný (Waldron 2009, 240-243). 
Na dolních hrudních a na bederních obratlích jsme identifikovali Schmorlovy uzly. Jedná se o porušení terminálních ploch obratlů v důsledku vychlípení jader meziobratlových disků (Vyhnánek 1999, 432; Waldron 2009, 45). Vizuálně je toto porušení velmi dobře rozeznatelné jako vklesnutí ve tvaru jamek či žlábků (Vyhnánek 1999, 432). Jedná se o důsledek stresu působícího na páteř (Waldron 2009, 45). Schmorlovy uzly mohou doprovázet Scheuermannovu nemoc, která postižené jedince předurčuje k časnému nástupu sekundární deformační spondylózy (Vyhnánek 1999, 432; Waldron 2009, 45).

\subsection{Radiokarbonové datování}

Pro radiokarbonové datování byl odebrán jeden drobný zlomek žebra, který byl volně vložený do relikviáře. Ze vzorku kosti byl extrahován kolagen, který byl následně datován metodou AMS. Měřen byl radioaktivní izotop 14C a stabilní izotop 13C (UGAMS 35116, tab. 1). Kalibrace byla provedena pomocí programu OxCal 3.1 za použití kalibrační křivky IntCal13 (Reimer et al. 2013, graf 1). Výsledky shrnuje tabulka 1. Naměřeno bylo datum $1780 \pm 20 \mathrm{BP}$, po kalibraci 142-332 AD (s pravděpodobností 95,4\%). Interval, který vymezuje smrt člověka, jehož ostatky byly uloženy do relikviáře, je v souladu s písemnými prameny, které udávají smrt sv. Felixe do roku 274.

\subsection{Prvková analýza kovových drátki̊}

Z poškozených částí relikviáře sv. Felixe byly odebrány tři odlišné vzorky kovových drátků sloužících k připevnění a výzdobě lidských kostí (obr. 9).

Vzorek 1 - zlatý drátek spletený ze dvou pramenů s roztepanými „osmičkami“ - tzv. leonský drátek podle města Lyon, považovaného za původní místo výroby (obr. 9)

Vzorek 2 - zlatý hladký drátek o průměru $0,2 \mathrm{~mm}$

Vzorek 3 - drátek spletený ze dvou pramenů

\begin{tabular}{|c|c|c|c|c|c|c|c|}
\hline vzorek & $\mathbf{C u}$ & $\mathbf{A u}$ & $\mathbf{A g}$ & $\mathbf{Z n}$ & $\mathbf{P b}$ & $\mathbf{N i}$ & $\mathbf{F e}$ \\
\hline 1 & 93,93 & 4,33 & 1,50 & - & - & 0,09 & 0,03 \\
\hline 2 & 91,35 & 5,71 & 2,71 & - & - & 0,11 & 0,05 \\
\hline 3 & 73,75 & - & - & 25,43 & 0,27 & 0,37 & 0,17 \\
\hline
\end{tabular}

Tab. 4. Výsledky měření a složení drátků odebraných z výzdoby z relikviáře sv. Felixe.

Tab. 4. Messergebnisse und Zusammensetzung der von der Verzierung aus dem Reliquiar des HI. Felix entnommenen Drähte.

Složení drátků bylo analyzováno pomocí metody rentgenové fluorescence s použitím ručního spektrometru Niton XL2 GOLDD. Výsledky měření jsou obsaženy v tabulce 3. V rámci omezeného počtu vzorků $(3 \mathrm{ks})$ se podařilo zachytit dva základní druhy materiálů použitých pro výrobu fixačních a ozdobných drátků v relikviáři sv. Felixe. Vzorky č. 1 a 2 jsou pravděpodobně vyrobeny ze stejného materiálu, kterým je pozlacený měděný drátek (pod mikroskopem lze $\mathrm{v}$ místech poškození povrchu pozorovat měděné jádro červené barvy). Zlacení obsahuje příměs stříbra. Vzorek č. 3 je vyroben z mosazi, bez stop drahých kovů. Není možno říci, zda se jedná o doklad pozdějších oprav relikviáře, anebo byly oba materiály využity již při jeho výrobě.

\subsection{Závěr}

K použití bioarcheologických metod k průzkumu ostatků, které byly od počátku přenesení do kostela Nejsvětější Trojice připisovány sv. Felixovi I., papeži (269-274), došlo po restaurování 


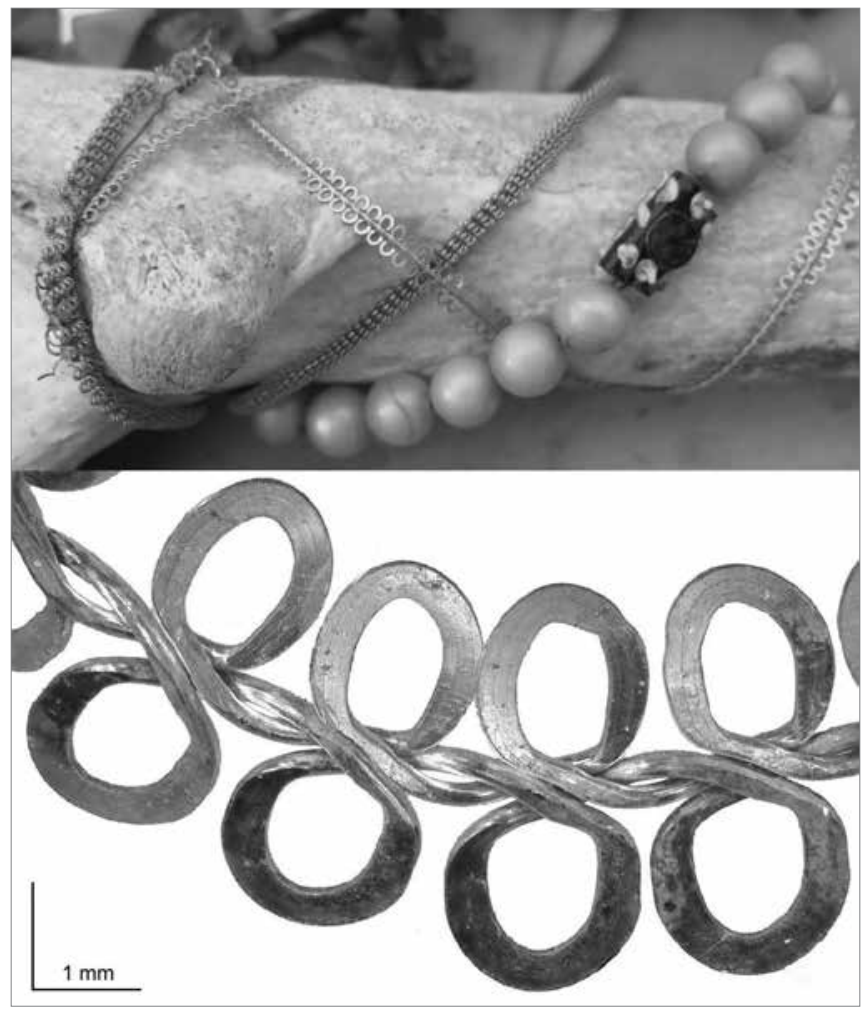

Obr. 9. Zlatý drátek spletený ze dvou pramenů s roztepanými obloučky ve tvaru osmiček. Foto J. John.

Abb. 9. Aus zwei Strähnen geflochtener Golddraht mit in die Form einer 8 ausgehämmerten Bögen. Foto J. John.

a opravě oltáře, a před restaurováním relikviářů, ve kterých jsou ostatky dnes uloženy. Autentika je dnes nezvěstná, a tak lze pouze spekulovat o původním místě uložení těchto lidských pozůstatků. Míra zachovalosti kostry byla velmi dobrá, ostatky byly téměř kompletní. Chyběly např́íklad obě loketní kosti. Povrch kostí byl bez poškození nebo druhotných úprav. Jednalo se o muže ve věku 21-24 let, výšky 162-171 cm. Po úrazu nebo nemoci měl zhojená lůžka po pravé druhé a třetí stoličce a u pravé třetí stoličky nejspíše nedošlo k prořezání. Na dolních hrudních a bederních obratlích byly rozeznány Schmorlovy uzly, které mohly vzniknout v důsledku stresu působícího na páteř. Radiokarbonové datování drobného zlomku kosti po kalibraci do 2.-4. století je v souladu s písemnými prameny, které udávají smrt Felixe I. do roku 274, tedy do druhé poloviny 3. století. Základními materiály honosné výzdoby, které byly použity na roztepaných a hladkých drátkách spletených ze dvou pramenů, byla pozlacená měd' a mosaz. Tato výzdoba společně s nejspíše látkovými drobnými kvítky byla vyrobena až pro slavnostní translaci v roce 1682 společně s jednotlivými schránami pro uložení na oltář sv. Archanděla Michaela.

\section{Diskuse a závěr}

Ostatky svatých z období baroka uložené v relikviářích jsou nestandardními památkami. Jednak př́stupem $\mathrm{k}$ tomuto tématu ze strany církve, ale i prostředím, ze kterého byly získávány. $\mathrm{V}$ posledních letech se $\mathrm{v}$ souvislosti s restaurováním těchto barokních relikviářu dostává do popředí právě bioarcheologie (více například Čechura 2010), která za pomoci moderních 
př́rodovědných metod pomáhá navrátit původní identitu - v tomto př́ípadě lidským - pozůstatkům, které byly vyzvednuty a původně pohřbeny v době římské v římských katakombách. Římské katakomby však nebyly pouze místem odpočinku raných křest’anů, ale i nejrůznějších etnik žijících v Římě, obyvatel nejrůznějších sociálních vrstev od otroků po zámožné římské rodiny. $\mathrm{Z}$ těchto katakomb byly od 16 . století vyzvedávány z původního místa uložení nejrůznější lidské pozůstatky ve velkém množství a distribuovány po celé tehdejší křest’anské Evropě jako ostatky svatých (více Timmermans 2012). Jejich translace a uložení v místě určení je tedy až druhotné, někdy jde o několikáté místo uložení, a k jejich původní identitě je vytvářena identita druhotná, církevní (více Prokopová 2011). Zvláštností těchto ostatkových památek je i přístup ze strany církve - ne vždy jsou k dispozici bioarcheologická data, která je možné získat právě při restaurování relikviářů a manipulaci s ostatky (Kracík-Horáková 2014). Jedněmi z prvních ostatků, které byly dány $\mathrm{k}$ dispozici na bioarcheologický průzkum - a to př́imo na základě žádosti ze strany církve -, byly ostatky sv. Auraciána z katedrálního kostela sv. Mikuláše v Českých Budějovicích, i když s omezeními (více Svatý Auracián v českobudějovické katedrále 2015). V této souvislosti je důležitý i metodologický postup při zpracování původně archeologického artefaktu druhotně uloženého již bez nálezových okolností. Bioarcheologie v tomto případě pracuje pouze s kosterními pozůstatky a díky široké škále nástrojů, jako je antropologie, radiokarbonové datování a řada dalších laboratorních analýz, může vytvořit profil života konkrétního sledovaného jedince (více např́íklad Stodder-Palkovich 2014).

\section{Prameny}

HOLEČEK, F., 2017: Poznámka k politickému a dogmatickému pozadí přenesení ostatků sv. Felixe, pocházejících z rrímských katakomb sv. Kalixta, do novobystřiického paulánského konventu Nejsvětější Trojice. Rukopis ulož. v archivu Jihočeského muzea v Českých Budějovicích.

CHERKINSKY, A.-ŠÁLKOVÁ, T., 2014: Zpráva o výsledcích radiokarbonového datování ostatků sv. Auraciána. Rukopis ulož. v archivu Jihočeského muzea v Českých Budějovicích.

- 2018: Zpráva o radiokarbonovém datování ostatku sv. Felixe z Kláštera u Nové Bystřice. Rukopis ulož. $\mathrm{v}$ archivu Jihočeského muzea v Českých Budějovicích.

\section{Literatura}

BAŽANTOVÁ, N., 1992: Relikviář sv. Maura, ZPP 52, č. 5, 1-6.

BOROVÝ, K., 1869: Láhvičky s krví sv. mučedníkův, Časopis katolického duchovenstva X, č. 1, 67-68.

BRONK RAMSEY, C., 2013: Calibration for Archaeological and Enviromental Terrestrial Samples in the Time Range 26-50 ka cal BP, Radiocarbon 55, č. 4, 2021-2027. https://doi.org/10.2458/azu_js_rc.55.16935

BRUZEK, J., 2002: A method for visual determination of sex, using the human hip bone, American Journal of Physical Anthropology 117, 157-168. https://doi.org/10.1002/ajpa.10012

BUIKSTRA, J. E.-UBELAKER, D. H., edd., 1994: Standards for Data Collection from Human Skeletal Remains. Fayetteville: Arkansas Archaeological Survey.

ČECHURA, M., 2010: Pohřební ritus ve středověku a novověku ve světle archeologického a antropologického výzkumu - Der Begräbnisritus im Mittelalter und der Neuzeit im Lichte der archäologischen und anthropologischen Forschung, AH 35, 111-119.

DOBISÍKOVÁ, M., 1999: Určování pohlaví. In: Stloukal, M. et al., Antropologie. Příručka pro studium kostry, 168-234. Praha: Národní muzeum.

- 1999: Určování věku. In: Stloukal, M. et al., Antropologie. Př́ručka pro studium kostry, 235-339. Praha: Národní muzeum.

DOBISÍKOVÁ, M.-ELIÁŠOVÁ, H., 2012: Forenzní antropologie. In: Štefan, J. et al., Soudní lékařství a jeho moderní trendy, 219-280. Praha: Grada.

FEREMBACH, D.-SCHWIDETZKY, I.-STLOUKAL, M., 1980: Recommendatios for age and sex diagnoses of skeletons, Journal of Human Evolution 9, 517-549. https://doi.org/10.1016/0047-2484(80)90061-5

FRANCE, D. L., 2009: Human and non-human bone identification. Boca Raton: CRC Press.

HENRY, R. J.-POST, A. C., 1989: A labially positioned mesiodens: case report, Pediatric Dentistry 11, č. 1, $59-63$. 
HUBER, K. L.-SURI, L.-TANEJA, P., 2008: Eruption disturbences of the maxillary incisors: a literature review, The Journal of Clinical Pediatric Dentistry 32, č. 3, 221-230. https://doi.org/10.17796/ jcpd.32.3.m175g3281100x745

CHERKINSKY, A., 2009: Can We Get a Good Radiocarbon Age from "Bad Bone"? Determining the Reliability of Radiocarbon Age from Bioapatite, Radiocarbon 51, č. 2, 647-655. https://doi.org/10.1017/ S0033822200055995

KADLEC, J., 1991: Přehled českých církevních dějin 2. Praha.

KOVÁŘ, D.-THOMOVÁ, Z., 2017: Výsledky záchranného archeologického výzkumu hřbitova a kostela sv. Mikuláše v Českých Budějovicích - Die Ergebnisse der archäologischen Rettungsgrabung auf dem Friedhof und an der Kirche St. Nikolaus in České Budějovice, AH 42, 617-649.

KRACÍK, P.-HORÁKOVÁ, M., 2014: Objev raně barokního relikviáře s ostatky sv. Sekundiny v kostele sv. Ignáce v Jičíně. In: Sborník k poctě Jiřího Kalfersta. AVČ - Supplementum 1, 164-198. Hradec Králové.

MEIGHANI, G.-PAKDAMAN, A., 2010: Diagnosis and management of supernumerary (mesiodens): a review of literature, Journal of Dentistry 7, č. 1, 41-49.

LOVEJOY, C. O., 1985: Dental wear in the Libben population. Its functional pattern and role in the determination of adult skeletal age at death, American Journal of Physical Anthropology 68, 47-56. https:// doi.org/10.1002/ajpa.1330680105

PROKOPOVÁ, Z., 2011: Barokní kult světců z katakomb na příkladu sv. Reparáta z kláštera minoritů v Českém Krumlově. In: Český Krumlov. Od rezidenčního města k památce světového kulturního dědictví (Gaži, M., ed.), 527-566. České Budějovice.

REBAN, K., 1918: Po stopách sv. Auraciána patrona města Č. Budějovic, Časopis katolického duchovenstva 9, 530-545.

REIMER, P. J. et al., 2013: Reimer, P. J.- Bard, E.-Bayliss, A.-Beck, J. W.- Blackwell, P. G.-Bronk Ramsey, C.- Buck, C. E.- Cheng, H.- Edwards, R. L.-Friedrich, M.-Grootes, P. M.-Guilderson, T. P.-Hajdas, I.-Hatté, C.- Heaton, T. J.-Hoffmann, D. I.-Hogg, A. G.-Hughen, K. A.-Kaiser, K. F.-Kromer, B.Manning, S. W.-Niu, M.-Reimer, R. W.-Richards, D. A.-Scott, E. M.-Southon, J. R.-Staff, R. A.Turney, C. S. M.- Van Der Plicht, J., INTCAL13 and MARINE13 radiocarbon age calibration curves, 0-50,000 years cal. BP, Radiocarbon 55, č. 4, 1869-1887. https://doi.org/10.2458/azu_js_rc.55.16947

RUSSEL, K. A.-FOLWARCZNA, M. A., 2003: Mesiodens - Diagnosis and management of a common supernumarary tooth, Journal of the Canadian Dental Association 69, č. 6, 362-366.

RYNEŠ, V., 1948: Čtení o sv. Oenestinovi: Příspěvek k dějinám české barokní zbožnosti, Věstník katolické osady jičínské IV, č. 3, 41.

SCHEINER, M. A.-SAMPSON, W. J., 1997: Supernumerary teeth: a review of the literature and four case reports, Australian Dental Journal 42, 160-165. https://doi.org/10.1111/j.1834-7819.1997.tb00114.x

SJØVOLD, T., 1990: Estimation of stature from long bones utilizing the line of organic correlation, Human Evolution 5, 431-447. https://doi.org/10.1007/BF02435593

STODER, L.-PALKOVICH, A., 2014: The Bioarcheology of Individuals. Florida.

STOJANOWSKI, C. M.-SEIDEMANN, R. M.-DORAN, G. H., 2002: Differential Skeletal Preservation at Windover Pond: Causes and Consequences, American Journal of Physical Anthropology 119, 15-26. https://doi.org/10.1002/ajpa.10101

SVATÝ AURACIÁN V ČESKOBUDĚJOVICKÉ KATEDRÁLE, 2015: Svatý Auracián v českobudějovické katedrále. České Budějovice.

TIMMERMANS, M., 2012: Roma Subterranea - The Catacombs of late antique Rome. BA thesis, Faculty of Archaeology, Leiden University.

UBELAKER, D. H., 1989: Human skeletal remains. Second edition. Washington D. C.: Taraxacum Press.

VYHNÁNEK, L., 1999: Nárys kosterní paleopatologie se zaměřením na radiodiagnostiku. In: Stloukal, M. et al., Antropologie. Př́ručka pro studium kostry, 386-432. Praha: Národní muzeum.

WALDRON, T., 2009: Palaeopathology. Cambridge: Cambridge University Press.

\section{Zusammenfassung}

\section{Bioarchäologische Untersuchungen der Reliquien von Heiligen aus Katakomben und ihren Translationen in der Barockzeit an bedeutende Orte in Südböhmen}

Gegenstand und Ziel der vorliegenden Studie ist die Auswertung bioarchäologischer Untersuchungen von Reliquien aus Reliquiaren, die gegenwärtig an bedeutenden, mit 
Kirchendenkmälern zusammenhängenden südböhmischen Orten aufbewahrt werden. In der Studie wurden zwei Fälle von Heiligenreliquien bearbeitet, die ursprünglich in den römischen Katakomben beigesetzt waren und denen eine neue Märtyeridentität geschaffen wurde. Die Reliquien gelangten im 17. Jahrhundert in die St. Nikolauskirche in České Budějovice und in die Dreifaltigkeitskirche in Klášter bei Nová Bystřice. Im Rahmen der Restaurierung der Reliquiare wurden auch anthropologische Analysen der Reliquien, eine Radiokarbondatierung und eine elementare Materialanalyse der Verzierungen der Reliquiare durchgeführt.

Die Reliquien des Hl. Auratianus aus der St. Nikolauskirche von České Budějovice, denen bei ihrer Translation die neue Identität eines römischen Soldaten geschaffen wurde, wurden aus anthropologischer Sicht untersucht, es wurde eine Radiokarbondatierung durchgeführt und eine nachträgliche Behandlung der Knochen beobachtet. Diese ursprüngliche Identität deckte die Tatsache auf, dass es sich dabei um menschliche Gebeine handelt, die aus den römischen Katakomben herausgenommen wurden und höchstwahrscheinlich einer Frau gehörten, an den Knochen wurde ein abgeheilter Bruch entdeckt und am Schädel ein überzähliger Zahn, ein sog. Mesiodens. Die Datierung dieser Reliquien fallen in die Jahrhundertwende, und vor der feierlichen Translation in die St. Nikolauskirche im Jahr 1670 wurde die Oberfläche der Knochen mit Wachs behandelt und mit einer Vergoldung versehen, die die Form von goldenen Spiralen hatte.

Bei dem zweiten untersuchten Individuum aus der Dreifaltigkeitskirche in Klášter bei Nová Bystřice ist keine Authentica überliefert, und der Legende nach handelt es sich um Papst Felix I. (269-274). In diesem Fall stand aus anthropologischer Sich besser erhaltenes Knochenmaterial zur Verfügung und Geschlecht, Lebensalter und Körpergröße konnten bestimmt werden. Es handelte sich um ein männliches Individuum im Alter von 21-24 Jahren mit einer Größe von 162-171 cm, datierungsmäßig können diese Reliquien im 2.-3. Jahrhundert n. Chr. angesiedelt werden. Die Reliquien wurden bei der Vorbereitung zur Translation verziert, und der größere Teil der Verzierung bestand aus unterschiedlich bearbeiteten Metalldrähten.

Die Bioarchäologie arbeitete in diesem Fall lediglich mit den Knochenüberresten ohne ursprüngliche Fundumstände, und nur Dank einer breiten Skala an Instrumenten wie die Anthropologie, Radiokarbondatierung und einer Reihe weiterer Laboranalysen konnte ein Grundprofil der konkreten untersuchten Individuen erstellt werden, denen in der Barockzeit eine sekundäre postume Identität geschaffen wurde.

Mgr. Zuzana Thomová, Jihočeské muzeum, Dukelská 1, 37001 České Budějovice; Archeologický ústav Filozofické fakulty Jihočeské univerzity v Českých Budějovicích, Branišovská 31a, 37005 České Budějovice, Česká republika,thomova@muzeumcb.cz

Mgr. Tereza Šálková, Archeologický ústav Filozofické fakulty Jihočeské univerzity v Českých Budějovicích, Branišovská 31a, 37005 České Budějovice, Česká republika, terezasalkova@seznam.cz

Mgr. Erika Průchová, Raisova 1776, 39701 Písek, Česká republika,epruchova@gmail.com

PhDr. Jan John, Ph.D., Archeologický ústav Filozofické fakulty Jihočeské univerzity v Českých Budějovicích, Branišovská 31a, 37005 České Budějovice, Česká republika, jjohn@jcu.cz

M. S. Alexander Cherkinsky, Ph.D., Center for Applied Isotope Studies, University of Georgia, Athens, GA 30602, USA, acherkin@uga.edu 
